\title{
Establishing priorities for the management and restoration of river basins with opencast coal mines
}

\author{
F. A. Comín ${ }^{1}$ J. M. Nicolau ${ }^{2}$, M. Trabucchi ${ }^{1}$, L. Miguel ${ }^{1}$, \\ S. Nyssen ${ }^{2} \&$ S. Pérez \\ ${ }^{1}$ Instituto Pirenaico Ecología-CSIC, Spain \\ ${ }^{2}$ Departament of Ecology, University of Alcala, Spain
}

\begin{abstract}
River basins with surface coal mines require restoration but priorities must be established hierarchically to achieve efficient river basin management. The watershed of River Martin $\left(1993 \mathrm{~km}^{2}\right.$ in NE Spain, Mediterranean continental climate) is characterized by a mountainous upper half part with low water flow regulation and a flat lower half with high water flow regulation (three reservoirs). Land cover of the upper part is scrub and wood (37\%) and dry agriculture (32\%), with some large natural areas $(8.5 \%)$ and open coal mine zones $(1 \%)$. Extensive dry agriculture dominates the lower part of the basin. Soil loss by erosion takes places at higher rates (average $125 \mathrm{Mg} \mathrm{ha}^{-1} \mathrm{yr}^{-1}$ ) in most of the upper part of the basin and at lower rates (average $27.5 \mathrm{Mg} \mathrm{ha}^{-1} \mathrm{yr}^{-1}$ ) in most of the lower part of the basin. Based on a combination of water runoff and soil loss, priorities for management actions of River Martin watershed should be given to areas covered by abandoned agriculture fields which did not develop a dense plant cover and extensive agriculture land use which may contribute high amounts of soil loss and pollutants to the river. A combination of the amount of soil loss estimated using RUSLE 1.06, a Revised version of the USLE, and the degree of soil conservation, let identify three mine zones in the upper part of the watershed as the major sources of sediment impacting the river waters. These are old reclaimed coal mines which require further restoration to decrease their high rates of soil loss. Water flow regulation and decreased water quality below the reservoirs, indicated by a biotic community dominated by hydrobids oligochaetes and gammarids, show that re-establishment of a dynamic water
\end{abstract}


regime and removal of pollutants is also a major objective for the integrated management and restoration of this river basin.

Keywords: river basin, ecology restoration, revised universal soil equation (RUSLE), surface coal mining reclamation, surface runoff generation, Spain, Mediterranean river, aquatic communities.

\section{Introduction}

The watershed has been recognized as the most adequate scale for the management of degraded rivers (Rhoni [10]). It has been also recently considered as a useful scale for planning the restoration of degraded rivers (Kershner [4]). However, planning river management and performing river restoration requires a broad knowledge of the watershed and the river characteristics to identify not only the environmental impacts but also their origins.

In watersheds with surface coal mining, both the whole watershed and the mine areas should be evaluated to define the scales of the restoration required to solve the environmental problems. Already restored coal mines should not represent a source of impacts but not restored or deficiently restored coal mines can represent a high deficiency by themselves for the watershed and also a source of impacts for the river basin (Sengupta [11]).

In order to manage a river basin efficiently priorities must be established for the objectives and particularly for the restoration actions to be performed (Kondolf and Micheli [5]). Again, the watershed approach must be used for establishing priorities. However, the presence of coal mines in bad conditions may open a controversy for coal mine scale versus river basin scale for prioritization of sites and of restoration actions (Hester and Harrison [2]).

In this work we present a method for the analysis of environmental problems in a river basin with open coal mines at different scales, including the watershed, the coal mines and the river scales and we use a qualitative assessment to establish priorities for the restoration at watershed scale. For this purpose, Martin River and its watershed in NE Spain was used. It is a typical rural semiarid river basin in a developed country, where intensive land use changes and degradation took place as natural resources were exploited for agriculture and mine industry during the $20^{\text {th }}$ century but also where intensive people emigration towards urban areas dominated the population dynamics while industrialization progressed in urban zones.

A Geographical Information System database was constructed for the watershed and land cover and physiographic characteristics were identified and validate in the field, and a vulnerability index was established for different zones of the watershed based on these characteristics and the estimated erosion rates. The ecological status of the river was assessed based on the water quality characteristics and using and indicator index from the biotic community living in the river. The mine zones in this watershed were classified based on their restoration status and potential impact on the river basin. Based on these 


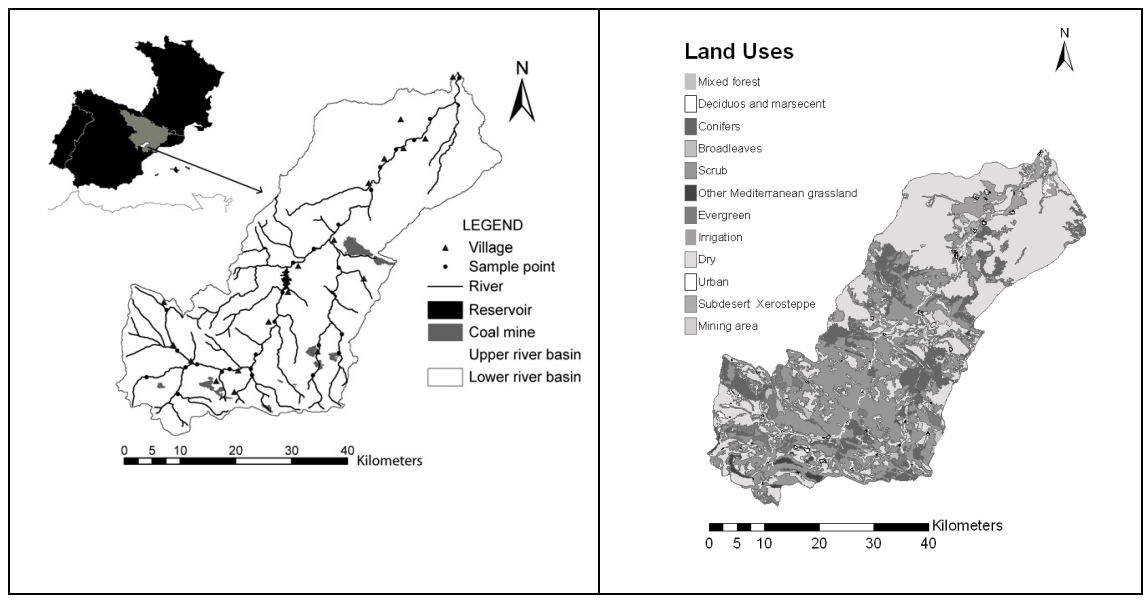

Figure 1: Geographic setting and major river network of Figure 2: Distribution of major Martin River Watershed. The shaded zone corresponds to the land cover identified in Martin River watershed. highlands and the white zone to the lowlands.

assessments, a hierarchical ordination of restoration actions at watershed scale is proposed and discussed.

\section{The watershed scale approach}

River Martin watershed is a $1,993 \mathrm{~km}^{2}$ area located in the south-central part of the Ebro River Basin (Fig. 1). After the Geographic Information System (GIS) elaborated, two major geographic zones were distinguished in this watershed: the highlands (800-1,620 m.a.s.l) in the south part of the basin occupy and area of $764 \mathrm{~km}^{2}$ which is drained by minor rivers (Segura, Parras, Fuenferrada, Cabra, Radón, Seco, Escuriza), and the lowlands (143-800 m.a.s.1.) in the north part of the basin which is drained by River Martin below the affluence of the other rivers and the lower part of the affluent Escuriza, which is regulated after a small reservoir (4 $\mathrm{Hm}^{3}$ water storage capacity) (Fig. 2). Most of the area in the lowlands $\left(737 \mathrm{~km}^{2}, 63 \%\right)$ is dedicated to agriculture, which is the major socioeconomic activity in the most populated villages: Albalate del Arzobispo 2,233, Hijar 1,920, Samper de Calanda 961, while mining is the stimulating socioeconomic activity for people living in the highlands (Utrillas 3.353, Montalban 1.477, Escucha 1.073. The population density in the lowlands $14 \mathrm{inh}$. $\mathrm{Km}^{-2}$ and 7 inh. $\mathrm{Km}^{-2}$ INE,2008 [3] in the highland) (Table 1). A reservoir, Cueva Foradada, (water storage capacity $35 \mathrm{Hm}^{3}$ ) in the main course of River Martin 
marks this change and separates the two mentioned parts. The highlands (average rainfall $500 \mathrm{~mm} /$ year) are mostly covered $(68 \%)$ by native bush and wood (Quercus sp pl.) plants and by reforested pines (Pinus sylvestris). Opencast active and used mine zones occupy $9,73 \mathrm{~km}^{2}$ in this zone. In the lowlands (average rainfall $370 \mathrm{~mm} /$ year), dry agriculture is the major land use but also $6,8 \%$ of the land is used for irrigated agriculture and $34 \%$ is occupied by natural bush plants.

Because of the major land cover and land covers identified using ARC MAP ${ }^{\odot}$ and field validation, some different environmental problems are identified for these two parts of the Martin watershed (Table 2).

Table 1: Distribution of major land cover identified in River Martin Watershed. Minor uses less than $1 \mathrm{Km}^{2}$ are not listed.

\begin{tabular}{|l|r|r|r|r|}
\hline \multicolumn{1}{|c|}{ Land cover } & \multicolumn{2}{c|}{ Highlands } & \multicolumn{2}{c|}{ Lowlands } \\
& \multicolumn{1}{c|}{$\mathrm{Km}^{2}$} & \multicolumn{1}{c|}{$\%$} & \multicolumn{1}{c|}{$\mathrm{Km}^{2}$} & \multicolumn{1}{c|}{$\%$} \\
\hline Mixed forest & 8.7 & 1.1 & 0.0 & 0.0 \\
\hline Deciduous and marsecent & 6.6 & 0.9 & 0.0 & 0.0 \\
\hline Conifers & 92.0 & 12.0 & 95.3 & 8.2 \\
\hline Broadleaves & 0.0 & 0.0 & 0.0 & 0.0 \\
\hline Scrub & 362.0 & 47.3 & 297.6 & 25.5 \\
\hline Other Mediterranean grassland & 15.8 & 2.0 & 1.5 & 0.1 \\
\hline Evergreen & 26.3 & 3.4 & 4.5 & 0.4 \\
\hline Irrigation & 16.5 & 2.2 & 79.9 & 6.8 \\
\hline Dry & 214.0 & 28.0 & 657.0 & 56.2 \\
\hline Urban & 3.15 & 0.4 & 5.3 & 0.5 \\
\hline Sub-desert xerosteppe & 0.0 & 0.0 & 10.7 & 0.9 \\
\hline Mining area & 9.7 & 1.3 & 7.7 & 0.7 \\
\hline
\end{tabular}

Table 2: Major environmental problems identified in the highlands and lowlands of River Martin Watershed.

\begin{tabular}{|l|l|}
\hline \multicolumn{1}{|c|}{ Highlands } & \multicolumn{1}{|c|}{ Lowlands } \\
\hline $\begin{array}{l}\text { Erosion by storm rainfall in poorly developed } \\
\text { natural plant cover }\end{array}$ & Erosion by intensive agricultural use \\
\hline $\begin{array}{l}\text { Air, soil and water pollution by opencast coal } \\
\text { mining activities }\end{array}$ & $\begin{array}{l}\text { Soil and water pollution by intensive use of } \\
\text { fertilizers in agriculture }\end{array}$ \\
\hline $\begin{array}{l}\text { Habitat loss and fragmentation by mining } \\
\text { activities }\end{array}$ & Habitat loss by extensive agriculture land use \\
\hline Landscape degradation by non-restored mines & $\begin{array}{l}\text { Landscape homogenization by extensive } \\
\text { agriculture land cover }\end{array}$ \\
\hline Biodiversity loss by mining activities & $\begin{array}{l}\text { Biodiversity loss by habitat loss and agricultural } \\
\text { uses }\end{array}$ \\
\hline Point source pollution from villages & Point source pollution from villages \\
\hline & Loss of river dynamics by reservoir regulations \\
\hline
\end{tabular}

Soil loss by erosion takes places at higher rates (average $125 \mathrm{Mg} \mathrm{ha}^{-1} \mathrm{yr}^{-1}$ ) in most of the upper part of the basin and at lower rates (average $27.5 \mathrm{Mg} \mathrm{ha}^{-1} \mathrm{yr}^{-1}$ ) in most of the lower part of the basin. In spite of the fact that opencast coal mines represent only $1.27 \%$ of the area of highlands, they contribute to a fragmented landscape which contrasts with the homogenization of the landscape 
at large scale in the lowlands, which is overwhelmingly dominated by large flat zones dedicated to non irrigated cereal agriculture (Fig. 2). In any case, both characteristics contribute to an impoverished biodiversity. Surface mine operations remove soil layers creating a dusty atmosphere which may last after the mine is closed if the mine area is not restored properly. This is a distinguished feature of the highlands in Martin watershed, as it is the loss of river dynamics in the lowlands as a consequence of flow regulation in the major reservoir.

A preliminary qualitative assessment of the services provided by the ecosystems in both parts of Martin watershed shows also an interesting contrast (Table 3). While provision of water and other services linked to the natural functioning of ecosystems, including biodiversity, takes place mostly in the

Table 3: Qualitative assessment of the ecosystem services provided by the group of habitats identified in the highlands and lowlands of River Martin Watershed.

\begin{tabular}{|c|c|c|}
\hline Ecosystem Service & Highlands & Lowlands \\
\hline Surface water supply & The most of the watershed & $\begin{array}{l}\text { Not significant, very low and } \\
\text { irregular rainfall }\end{array}$ \\
\hline Water supply and regulation & $\begin{array}{l}\text { Relevant in natural } \\
\text { vegetated habitats }\end{array}$ & Not significant \\
\hline Soil retention and formation & $\begin{array}{l}\text { Relevant in natural densely } \\
\text { vegetated zones but intense } \\
\text { soil erosion in some non- } \\
\text { vegetated parts of the } \\
\text { watershed and in some } \\
\text { mine zones non/bad } \\
\text { restored. }\end{array}$ & $\begin{array}{l}\text { Not significant or very negative } \\
\text { because of intensive ploughing }\end{array}$ \\
\hline Nutrient regulation & $\begin{array}{l}\text { Relevant in well preserved } \\
\text { habitats/Stressed in mine } \\
\text { zones }\end{array}$ & $\begin{array}{l}\text { Stressed because of used of } \\
\text { fertilizers and pesticides for } \\
\text { agriculture }\end{array}$ \\
\hline Pollination & $\begin{array}{l}\text { Important because of the } \\
\text { dense plant cover }\end{array}$ & Not relevant \\
\hline Carbon storage & $\begin{array}{l}\text { Relatively important in old } \\
\text { forests. } \\
\text { Extremely negative as } \\
\text { mining removes fossil } \\
\text { carbon storages. Partially } \\
\text { compensated in restored } \\
\text { coal mines. }\end{array}$ & $\begin{array}{l}\text { Negative performance after } \\
\text { years of intensive conventional } \\
\text { agriculture land use. }\end{array}$ \\
\hline Biodiversity provision & $\begin{array}{l}\text { Important in relation to the } \\
\text { variety of habitats present } \\
\text { in this zone. Recognized } \\
\text { by the establishment of } \\
\text { officially preserved zones. }\end{array}$ & $\begin{array}{l}\text { Much less relevant compared to } \\
\text { those in the highlands. }\end{array}$ \\
\hline Food production & Not significant & Very important \\
\hline Raw materials & $\begin{array}{l}\text { Still important for carbon } \\
\text { and dependent } \\
\text { economic dynamics. }\end{array}$ & Not significant \\
\hline Cultural use & $\begin{array}{l}\text { Valuable landscape but in } \\
\text { degraded mine zones }\end{array}$ & Invaluable landscape \\
\hline
\end{tabular}


highlands, food production is mostly provided by the lowlands,. A special interest comes up for the highlands as the mine zones provide carbon used for energy production. It must be indicated that a few opencast mines for clay and other products used for building are also operated in the highlands. A recent crisis of this economic activity makes it uncertain to evaluate their impact to provide ecosystems services. However, their negative impact in the watershed environment is similar to that of the coal mines.

In general, the lowlands are valuable for food production as most of its area is dedicated to agricultural use, but this extensive use and the homogenized landscape do not provide other ecosystem services. In contrast, the highlands provide a good number of ecosystem services and not so much food products. However, the presence of degraded open coal mines contributes negatively to the general value of this part of the watershed.

\section{The mine scale approach}

The small portion of the River Martin Watershed occupied by surface coal mining $\left(27.2 \mathrm{~km}^{2}, 0.8 \%\right.$ of the total watershed area, Fig. 2) is not equivalent to its environmental, social and economic importance. For most of the second part of the $20^{\text {th }}$ century coal mining and electricity production were the essential economic support of the watershed population. By the end of the seventies of the last century, surface mining was introduced closing most of the underground exploitations. This technological change led to a drastic reduction of employments as well as to a much higher environmental impact of the activity.

After a boom of the surface mining at the 1980s (17 mines, 2.500 has), the activity has strongly declined with only three mines operating. Right now reduction is expected by 2012 when the EU subsides will end. Some exploitation of clays and limestone has been open in last years but the present crisis has slowed this activity. A great effort of public investment is being developed with EU subsides in order to mitigate the socioeconomic depletion after mining closing. The coalfield has been declared as Mining Zone in Modernization, so that important infrastructures have been constructed and the increasing recreational activity -based on the cultural and natural heritage of this region- has been supported

This takes the mine zones to the point of considering what to do after the end of the exploitation period for which it is necessary to know their present ecological status and their assessment in relation with the river basin management. The 17 surface coal mines of River Martin Watershed can be distributed according to their restoration status (Nyssen [8]) indicated by the plant coverage (successfully restored versus non-successfully restored: respectively more or less than $40 \%$ plant coverage) and the status of the substratum (degraded versus preserved: respectively with or without networks of rill erosion tracks). The late is a characteristic related to soil erosion, which is a major factor to define the restoration success for mine zones $[1,7]$. Then, in River Martin watershed 8 mines are in good ecological status as they are restored and preserved; and 9 are in bad ecological status, as they are either non-restored 
(3), or restored and degraded (6). These 9 mines can be considered the environmental passive heredity of 30 years of surface coal mining.

In addition, two other characteristics are important to assess the impact of coal surface mines: the type of hydrologic design (being or not connected with the river network via surface flow) and the type of geomorphic design (as the old slope bank-berm-ditche versus a more natural catchment-simulating design). In River Martin watershed a few mine zones are endorreic basins with a surface design simulating natural geomorphology. These zones do not export sediment to the river network. A few mine zones were restored simulating natural landforms but connect to the river network. These contribute a very low soil loss. Most of the soil loss running off towards the rivers takes place in old mine zones restored following the slope bank-berm-ditche system $(5,000 \mathrm{Mg} /$ year) while a very few non-restored mines export solids to the rivers at a rate of $100 \mathrm{Mg} /$ year (Fig. 3).

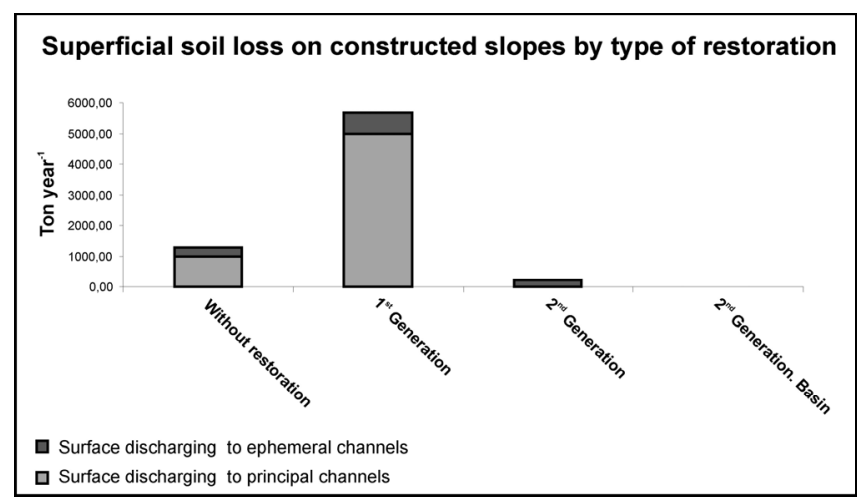

Figure 3: $\quad$ Superficial soil loss on constructed slope by type of restoration.

The rate of sediment emissions from mines towards natural watercourses could be one of the criteria to make a hierarchical selection of the mines in order to face up their reclamation with public, and so limited, funding. This should be completed with the assessment of the conservation status of the aquatic ecosystems receiving mining sediments.

\section{The river scale approach}

River Martín is a typical small Mediterranean river with a mean annual water discharge of $97 \mathrm{Hm}^{3}$. The water flows with a natural regime in the upper part of the basin but it is regulated by the above mentioned reservoirs in the lower part of the basin.

In July 2008, water and macroinvertebrate samples were collected from 27 sites along the two river sections and their hydro-morphological characteristics were recorded (data can be seen in table 4). Data were treated statistically using SPSS and CANOCO software. An ANOVA analysis was performed to find differences between the two sections of Martín River and a Principal Components Analysis (PCA) with environmental variables and a 
Table 4: $\quad$ Descriptive statistics for studied variables and ANOVA results.

\begin{tabular}{|c|c|c|c|c|c|c|c|c|c|}
\hline \multirow[b]{2}{*}{ Variable } & \multicolumn{3}{|c|}{ UPPER BASIN } & \multicolumn{3}{|c|}{ LOWER BASIN } & \multicolumn{3}{|c|}{ ANOVA } \\
\hline & Minimum & Maximum & Average & Minimum & Maximum & Average & gl & $\mathbf{F}$ & Sig. \\
\hline Flow $\left(\mathrm{m}^{3} / \mathrm{s}\right)$ & 0,00 & 0,37 & 0,11 & 0,03 & 1,91 & 0,67 & 1,00 & 9,68 & 0,01 \\
\hline $\begin{array}{c}\text { Temperature } \\
\left({ }^{\circ} \mathrm{C}\right)\end{array}$ & 12,80 & 20,20 & 16,23 & 18,80 & 22,20 & 20,15 & 1,00 & 27,23 & 0,00 \\
\hline $\begin{array}{c}\text { Dissolved } \\
\text { oxigen }\left(\mathrm{O}_{2}\right) \\
(\mathrm{mg} / \mathrm{l}) \\
\end{array}$ & 7,76 & 12,21 & 9,40 & 5,71 & 9,01 & 7,33 & 1,00 & 25,45 & 0,00 \\
\hline $\begin{array}{c}\text { Conductivity } \\
(\mu \mathrm{S} / \mathrm{cm})\end{array}$ & 508,00 & 1908,00 & 926,88 & 570,00 & 2880,00 & 1664,64 & 1,00 & 9,91 & 0,00 \\
\hline $\mathrm{pH}$ & 7,70 & 8,60 & 8,23 & 7,80 & 8,40 & 8,06 & 1,00 & 3,33 & 0,08 \\
\hline $\begin{array}{c}\text { Total } \\
\text { suspended } \\
\text { solid }(\mathrm{mg} / \mathrm{l})\end{array}$ & 2,00 & 11,50 & 6,14 & 2,86 & 47,60 & 19,84 & 1,00 & 13,52 & 0,00 \\
\hline $\begin{array}{c}\text { Suspended } \\
\text { organic matter } \\
(\mathrm{mg} / \mathrm{l})\end{array}$ & 0,00 & 8,40 & 1,95 & 0,00 & 6,00 & 3,41 & 1,00 & 2,77 & 0,11 \\
\hline $\begin{array}{l}\text { Total dissolved } \\
\text { solid (mg/l) }\end{array}$ & 324,00 & 1704,00 & 703,75 & 360,00 & 2940,00 & 1566,55 & 1,00 & 9,85 & 0,00 \\
\hline $\begin{array}{c}\text { Alkalinity } \\
\text { (Alc) (mg/l) }\end{array}$ & 168,60 & 305,70 & 217,01 & 127,30 & 212,20 & 173,06 & 1,00 & 13,11 & 0,00 \\
\hline $\mathrm{NH}_{4},(\mathrm{mg} / \mathrm{l})$ & 0,00 & 0,00 & 0,00 & 0,00 & 2,75 & 0,25 & 1,00 & 1,48 & 0,24 \\
\hline $\mathrm{NO}_{2},(\mathrm{mg} / \mathrm{l})$ & 0,01 & 0,11 & 0,03 & 0,01 & 1,21 & 0,19 & 1,00 & 4,64 & 0,04 \\
\hline $\mathrm{NO}_{3},(\mathrm{mg} / \mathrm{l})$ & 1,51 & 40,05 & 9,51 & 1,02 & 16,82 & 8,83 & 1,00 & 0,03 & 0,86 \\
\hline $\begin{array}{c}\text { Total inorganic } \\
\text { nitrogen, } \\
(\mathrm{mg} / \mathrm{l})\end{array}$ & 0,35 & 9,07 & 2,16 & 0,26 & 3,85 & 2,25 & 1,00 & 0,18 & 0,68 \\
\hline $\mathrm{P}_{-} \mathrm{PO}_{4}(\mathrm{mg} / \mathrm{l})$ & $<0,006$ & 1,82 & 0,15 & $<0,006$ & 0,30 & 0,05 & 1,00 & 0,42 & 0,52 \\
\hline $\begin{array}{c}\text { Family } \\
\text { richness }\end{array}$ & 14,00 & 26,00 & 20,20 & 12,00 & 24,00 & 17,73 & 1,00 & 3,13 & 0,09 \\
\hline ETP & 4,00 & 12,00 & 8,47 & 3,00 & 9,00 & 6,27 & 1,00 & 6,61 & 0,02 \\
\hline $\begin{array}{l}\text { Shannon } \\
\text { (bits/ind) }\end{array}$ & 0,69 & 2,20 & 1,61 & 0,51 & 2,06 & 1,42 & 1,00 & 1,02 & 0,32 \\
\hline Simpson & 1,83 & 3,96 & 2,72 & 1,61 & 3,43 & 2,32 & 1,00 & 0,16 & 0,69 \\
\hline QBR & 37,00 & 80,00 & 61,25 & 36,00 & 72,00 & 57,45 & 1,00 & 0,21 & 0,65 \\
\hline IHF & 5,00 & 95,00 & 27,00 & 0,00 & 55,00 & 23,64 & 1,00 & 0,64 & 0,43 \\
\hline
\end{tabular}

Correspondence Analysis (CA) with macroinvertebrate families were applied to see the sampled point distribution.

The ANOVA analysis (table 4) shows significant differences with respect to the water characteristics, although not in all the studied variables. Nevertheless, there are not been great differences in macroinvertebrate index, although there are differences between the two sections in family dominance and ETP index. And they are not differences in the state of conservation of the riverside, QBR, (Munné et al. [6]) that is critical in all the Martín River Basin (67\% of sampled points has a terrible quality and $22 \%$ a bad quality) and the fluvial habitat, IHF, (Pardo et al. [9]) with that is quite homogenous also in the two sections. It indicates that the river habitats in this basin have been intensively transformed into other uses and, therefore, degraded.

In PCA the two first components accounted for $62 \%$ of all the data variation. The second component (PCA 2, 23\% of the total variance) was constituted by T, 
$\mathrm{O}_{2}$ and Alc and is the component that better separates the upper and the lower river basins (Fig. 4(b)). The PCA graphic representation shows as most of sampling points are grouped within the categories upper and lower basin. The four exceptions corresponding to sampled points in rivers affected by coal mining (4(b)) and by sewage treatment plant (4(a)).

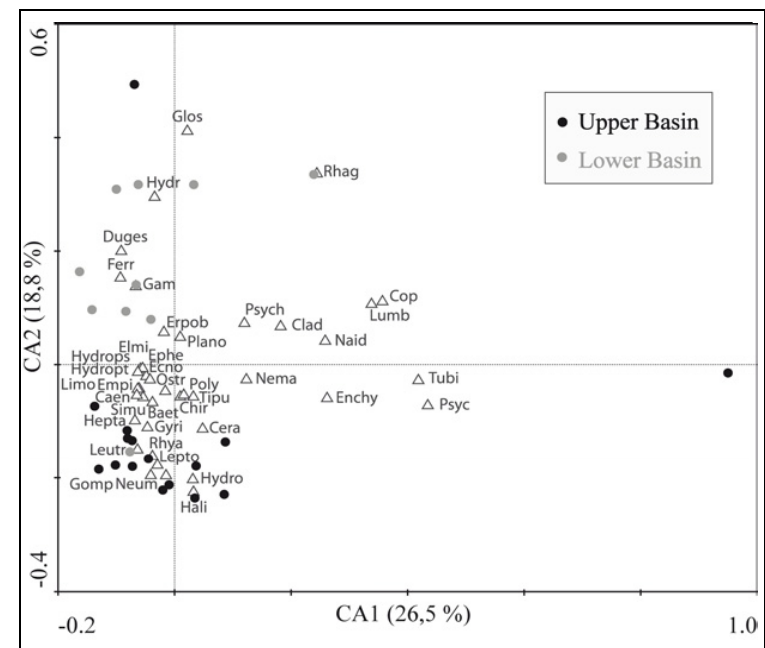

(a)

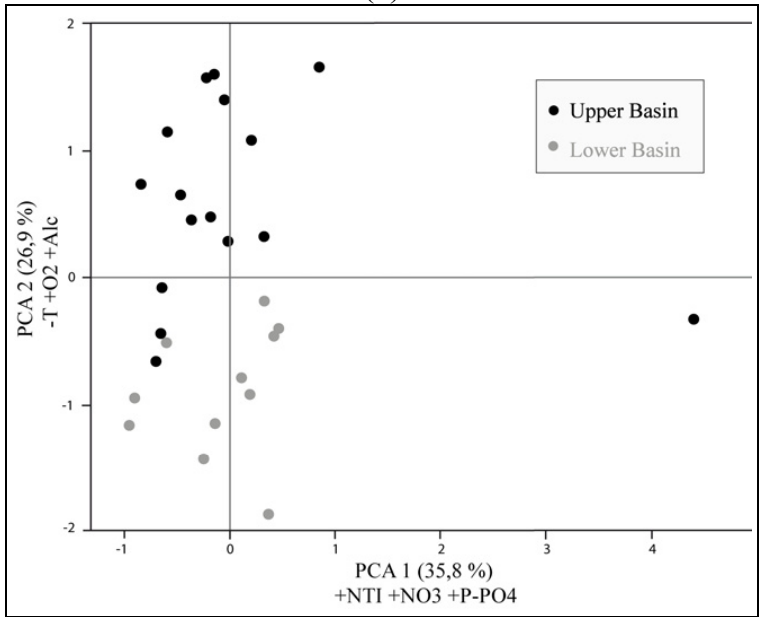

(b)

Figure 4: (a) Scores of river water samples defined by the first two components from the Principal Component Analysis (PCA). (b) Scores of river water samples and the abundance of family macroinvertebrate defined by the first two axes from the Correspondence Analysis (CA). 
On the other hand, we have the results of CA. The first two axes of the CA, applied with abundances of macroinvertebrate families, explained $45,3 \%$ of data variance. The graphical representation (Fig. 4(a)) shows the division of the river basin into the two predefined sections. Again there are three exceptions to this general distribution that correspond with sites influenced by coal mine and wastewater discharges. In addition, this analysis shows a clear segregation by taxons between the upper and the lower river Martín sections.

In summary, the water in the Upper River Basin had higher $\mathrm{pH}$, alkalinity, oxygenation, and slightly higher nitrate and phosphorus concentration than in the lower part of the basin. The aquatic communities in the upper basin were dominated by insects (e.g., Baetidae, Simulidae and Chironomidae) and exhibited higher ETP (Ephemeroptera-Tricoptera-Plecoptera) richness and slightly higher family richness than the Lower River Basin. Conversely, the Lower River Basin had higher flow discharge, temperature, conductivity, hardness and slightly higher nitrite and ammonium concentration and was dominated by gastropods (e.g., Hydrobiidae) and crustaceans (e.g., Gammaridae), albeit oligochaetes (e.g., Tubidificidae) and insects (e.g., Baetidae, Hydropsychidae) were also abundant. These differences indicate a better water quality for the river reaches in the upper than in the lower part of Martin watershed.

These results show that, in our study zone, differences in hydrology and landuse in the two sections entail differences in water and macroinvertebrate community, but not in riverside vegetation quality and fluvial habitat diversity which showed an intense and general degradation.

\section{Overview}

Based on the diagnostic presented above the following criteria can be adopted for the management and restoration of River Martin Watershed. Management of River Martin basin requires the definition of a sustainable land use plan and the restoration of degraded sites as part of it. As the major environmental impacts (erosion, habitat loss, degraded water quality) both in the watershed and in the rivers are originated in the terrestrial part of the watershed (some mine zones, intense agriculture use, habitat loss by land cover change, water flow regulation, point source pollution), the solutions must be initiated by eliminating the origins of the problems and later by re-covering degraded sites.

River basin management at watershed scale requires the definition of ecosystem features both in the watershed and in the river (Van Rooij et al. [13]). In semiarid areas, common environmental impacts are related with the combination of soil erosion, extensive use of land by intensive agriculture, water flow regulations in the river and loss of water quality by point and non-point source pollution. In River Martin watershed, the presence of mine zones incorporates a major source of impacts whose restoration must be integrated into the basin management through the prioritization of restoration sites and restoration actions. Here, it has been established as prioritized sites a few opencast coal mine zones none (or wrongly) restored which export solids to the 
river network. It has been suggested as prioritized actions to restore a more natural surface morphology and, if possible, closed watershed for these mine zones. However, a higher priority has been defined at watershed scale for the ecological revegetation of degraded sites in the watershed (zones with low plan density in the upper part of the basin and ecological buffer strips and corridors in the lower part of the basin which is extensively used for intensive agriculture) (Table 5). Further recovery of a river water regime and river habitats will succeed after these prioritized actions were implemented.

Table 5: $\quad$ Prioritized management and restoration actions in the River Martin watershed and expected ecosystem responses.

\begin{tabular}{|c|c|c|c|c|}
\hline Priority & Degradation & Scale & Action & $\begin{array}{l}\text { Expected ecosystem } \\
\text { response }\end{array}$ \\
\hline 1 & Erosion & Basin & $\begin{array}{l}\text { Integrative topographic } \\
\text { recovery, revegetation and } \\
\text { soil retention structures in } \\
\text { the upper part of the basin. } \\
\text { Creation of buffering } \\
\text { strips between agriculture } \\
\text { fields and ecological } \\
\text { corridors in the lower } \\
\text { basin }\end{array}$ & $\begin{array}{l}\text { Plant/soil recovery, } \\
\text { buffered water flows, } \\
\text { recreation of habitats }\end{array}$ \\
\hline 2 & Erosion & $\begin{array}{l}\text { Mine } \\
\text { zone }\end{array}$ & $\begin{array}{l}\text { Reconstruct the surface of } \\
\text { the few mine zones } \\
\text { exporting huge amounts of } \\
\text { solids towards the rivers } \\
\text { establishing more natural } \\
\text { (may be closed) mine } \\
\text { watershed. }\end{array}$ & $\begin{array}{l}\text { Stop soil erosion, re- } \\
\text { establishment of an } \\
\text { ecosystem community } \\
\text { after initial plant } \\
\text { inoculums. }\end{array}$ \\
\hline 3 & Habitat loss & River & $\begin{array}{l}\text { Restoration of } \\
\text { hydromorphological } \\
\text { features of river channels } \\
\text { in degraded reaches; direct } \\
\text { and indirect recreation of } \\
\text { riverine woodlands. }\end{array}$ & $\begin{array}{l}\text { Recovery of riverine } \\
\text { habitats and river } \\
\text { reaches. }\end{array}$ \\
\hline 4 & $\begin{array}{l}\text { Water flow } \\
\text { regulation }\end{array}$ & Dams & $\begin{array}{l}\text { Re-establishment of a } \\
\text { more natural water flow } \\
\text { regime in the lower part of } \\
\text { River Martin according to } \\
\text { social demands. }\end{array}$ & $\begin{array}{l}\text { More diverse hydro- } \\
\text { ecological features, auto } \\
\text { depurative capacity, } \\
\text { habitat and biological } \\
\text { communities recovery }\end{array}$ \\
\hline
\end{tabular}

\section{Conclusions}

The analysis of environmental impacts and potential solutions for Martin River Basin (NE Spain) shows that a downscaling approach is recommended for the management and restoration of river basins with opencast coal mines. At basin scale, habitat recovery requires re-vegetation and establishing buffering systems for soil retention and accumulation. At mine scale, the restoration program must consider a physical design resembling natural terrain surfaces and endorheic subwatersheds to avoid connection with the river network. At river channel scale, recovery of riparian habitats and in-channel habitats must be performed after the previous ones and after point source pollution treatment. 


\section{Acknowledgements}

This work was developed after Convenio Endesa S.A.-CSIC. Thanks are given to people working at Minas Endesa-Teruel for their support and collaboration. M.T., L.M. and S.P. were on receipt of grants from CSIC, Aragon Government and University of Alcala, respectively.

\section{References}

[1] Evans, K. 2000. Methods for assessing mine sites rehabilitation design for erosion impact. Australian Journal of Soil Research 38:231-247.

[2] Hester, R.E. and Harrison, R.M. 1994. Mining and its environmental impact. Issues in Environmental Science and Technology. RSC Publishing

[3] INEbase, Demografía y población. Cifras de población y Censos demográficos, www.ine.es/

[4] Kershner, J.I.. 1997. Setting riparian/aquatic restoration objectives within a watershed context. Restoration Ecology 45:15-24.

[5] Kondolf, G. M. and E. R. Micheli. 1995. Evaluating stream restoration projects. Environmental Management 19 (1): 1-15.

[6] Munné, A. Sola, C. Rieradevall, M \& Prat, N.; 1998 Índice QBR. Método para la evaluación de la calidad de los ecosistemas de ribera. Estudios de la calidad ecológica de los ríos, 4, 28 pp. Área Medio Ambiente, Diputación de Barcelona

[7] Nicolau, J.M. and Asensio, E. 2000. Rainfall erosion on opencast coal mine lands: Ecological perspective. In Reclaimed Land: Erosion control, soils and ecology. Haigh, M.J. (ed.). A.A. Balkema, Rotterdam, 51-73.

[8] Nyssen, S. 2007.Contribución a la evaluación del impacto hidrológico de la minería a cielo abierto en Teruel: Estimación de la emisión de sedimentos con el modelo RUSLE. Universidad de Alcalá de Henares (Unpublished Degree Report at the Department of Ecology-UAH).

[9] Pardo, Isabel; Álvarez, Maruxa; Casas, José Luis; Moreno, José Luis; Vivas, Soledad; Bonada, Núria; Alba- Tercedor, Javier; Jáimez, Pablo; Moyá, Guillem; Prat, Narcís; Robles, Santi; Suárez, María Luisa; Toro, Manuel; Vidal-Abarca, María Rosario (2002). «El hábitat de los ríos mediterráneos. Diseño de un índice de diversidad de hábitat». Limnetica, núm. 21 (3-4). Pag. 115-133.

[10] Rhoni, P. 2005. Monitoring stream and watershed restoration. American Fisheries Society, Bethesda., 350 pp.

[11] Sengupta, M. 1993. Environmental impacts of mining. Monitoring, restoration and control. Lewis Publishers.

[12] Suárez, M.L., et al., Las riberas de los ríos mediterráneos y su calidad: el uso del índice QBR. Limnética, 2002. 21: p. 135-148.

[13] Van Rooij, S.A.M.,W.M. Liefveld \& G.J. Mass. 2001. Guidelines for spatial distribution of ecotopes, based on ecological networks and geomorphological boundary conditions. River Basin Management. In R. A. FALCONER (ed.). River Basin Management. Ecology and the Environment volume 50, pag. 